Mr. Paget divides his handbook into two parts, the first relating to the right construction of schools, and the second to their right administration. Under the former head he discusses in succession the questions of the site, soil, and aspect best suited for the erection of schools; the due provision of light and of air, and the importance of a good supply of water both for drinking and for cleanliness. His estimate of the space required for each child appears to be excessive, and to be almost the only feature of his work which betokens a lack of practical experience, and a striving after an unattainable ideal. It is well known that the minimum space recognised by the Education Department under any conditions as sufficient is eight square feet of area, or eighty cubic feet of internal space for each child ; but in schools built by Boards, or out of funds levied by rates, the Department insists on a larger provision, i.e. ten square feet of area and 120 cubic feet. Any one familiar with well-planned Board Schools of a modern type knows well that this space suffices to secure ample room for movement, for change of position for the arrangement and supervision of classes, and for a due supply of air. It will, therefore, be somewhat startling to school managers to learn that in Mr. Paget's opinion this provision is absurdly insufficient, and that 800 or even $\mathrm{I}, \infty 00$ cubic feet per scholar would not be too much. Perhaps it is wrong in such a connection to dwell on the question of expense. But when it is considered that the building of a good school, apart from the cost of the site, requires an expenditure of $\mathrm{rol}$. per head-a great London Board School for, say, 500 boys, 500 girls, and 600 infants, in three stories costing about 16,000 l. - it will be easy to compute what would be the charge on the rates if each of the $\mathrm{I}, 600$ children were to be furnished with an area of forty or fifty square feet in a room twenty feet high. The estimate is clearly enormous, and can certainly not have been founded on an observation of the actual dimensions of any school, whether elementary or secondary. Apart, however, from the consideration of expense, it may well be doubted whether such vast space would in any circumstances be needed. For the purposes of teaching and organisation a certain compactness of arrangement is clearly desirable, and the supervision of the head teacher becomes more difficult and less complete in proportion to the size of the area over which the work of the school is spread. These are considerations, however, which it would be right to overrule, if on sanitary grounds there were any necessity for such large spaces. But when the ordinary precautions which Mr. Paget suggests for insuring light cheerfulness and ventilation are taken, it is scarcely credible that any such necessity actually exists. Mr. Paget's estimate of the amount of cubic space needed in boarding schools, in cubicles, and dormitories, is not so large in proportion, and is indeed not wholly consistent with the demands he makes for space in a purely day school. Nevertheless, by placing it at I,200 cubic feet per scholar, he practically condemns the arrangements in almost every boarding school in England; for the usual requirements are thought to be well fulfilled with exactly half that amount.

On the extent of the window-space, the provision of fresh air, the right construction and care of offices, the colouring of walls, the admission of light, the right attitude of the scholar, and the distance of his book in reading or writing, and the form of desks, the handbook abounds in judicious and definite suggestion. It is much less full and useful, however, in regard to the fitting of playgrounds, the organisation of games, and recreations generally. Teachers will be disappointed to find how little of practical guidance the book affords as to the best and healthiest forms of recreation, and the proportion which should exist between regulated gymnastics and the free spontaneous exercis ${ }^{\circ}$ s which all boys and many girls can readily discover for themselves. On diet, bathing, sanatoria, and many details which specially concern boarding schools, Mr. Paget's advice is especially valuable and complete. His estimate of the time per day which may with full regard to all considerations of health be given to intellectual pursuits, will surprise some of his medical brethren who have been complaining of late of the ordinary school hours as excessive, and have been denouncing little home-tasks of half an hour long in the elder classes as a "burden too grievous to be borne." He computes that between the ages of seven and ten five hours a day is probably sufficient, and between the ages of ten and fifteen seven hours. When it is considered that even the elder and more diligent pupils in an elementary school are never under instruction more than five and a half hours a day for five days in the week, and that the hardest home-lessons ever given in such a school do not occupy nearly an hour a day; and when it is also considered that even in the girls' high school--in which the justest complaints have been made of excessive hometasks lasting sometimes two hours-the actual attendance in the school itself is generally limited to four hours, it will be seen that the absurdly exaggerated modern outcry about over-strain receives no countenance from Mr. Paget. His own good sense and experience, in short, lead him to recognise the fact that after all the chief business of the boy's or girl's life is training and instruction ; and that provided all needful precautions are taken for right distribution and variety of work, and for securing all the conditions of healthy and cheerful life, the hours usually devoted to education in England do not exceed a reasonable amount, but rather fall short of them.

It is not the least of the merits of the book that its suggestions are put forth modestly, and with a remarkable absence of dogmatism. When the writer is not quite sure of his ground he is careful to say that his remarks are tentative and suggestive only, intended to awaken interest in the subject rather than to exhaust it; and to lead the way to a fuller and more careful study of the whole theory of school hygiene with the aid of the numerous appliances now on view at the Exhibition. This reticence on points not yet finally settled tends greatly to increase the confidence of the reader in Mr. Paget's judgment on those topics on which he expresses a decided opinion.

\section{NOTES FROM THE LEYDEN MUSEUM}

I $T$ was a very happy thought of the late Prof. Schlegel to publish under the above title a quarterly record of the work done in the Royal Zoological Museum of the Netherlands at Leyden. The publication commenced in 1879 , and the five yearly volumes before us, edited by Prof. Schlegel, will be one of the several enduring monuments to his memory. To all those interested in zoological research, the important treasures of the Leyden Museum are of necessity known. However indebted the Museum was to the well-known labours of Temminck, it is to the zeal and knowledge of Schlegel that it occupies its present high position among the museums of Europe. A very few words will show the importance from a zoological standpoint of these volumes, which contain on an average 250 pages each. The first volume contains descriptions of new species of mammals, birds, reptiles, insects, crustacea, and worms. These descriptions are for the most part by the director of the Museum and his Assistants, but help seems also welcomed from every hand, and the well-known names of R. B. Sharpe, P. Herbert Carpenter, Dr. D. Sharpe, Rev. H. S. Gorham, Prof. J. O. Westwood, occur among the British contributors. Besides containing ntmerous diagnoses of new species, these notes also from time to time present us with very important critical essays. Thus, in vol. i. Dr. A. A. W. Hubrecht's "Genera of European Nemerteans critically" revised, with Descriptions of New Species," with a first appendix in vol. ii., is of great interest. It gives, so far 
as European forms are concerned, a classification of the genera and details of the species found at Naples. With regard to a genus of De Blainville, Lobilabrum, which was founded on a single specimen of the species $L$. ostrearum, and which has never been again met with, the following instructive facts are recorded. This genus was easily distinguished from all others by the possession of a blunt snout with two horizontal lips at the extremity, both of them bilobed, and apparently with tentacles. The slit between the lips was described as being a continuation of the lateral fissures of both sides of the head. In other respects the genus bore a strong resemblance to species of Lineuis or Cerebratulus living in the same localities. One day at Naples Dr. Hubrecht was fortunate enough to come across a second specimen of this rare worm, which, like De Blainville's specimen, was dredged from a bottom covered with bivalve shells. It was duly figured and preserved, and longitudinal sections were made of its curious snout. Soon after he was struck by the extraordinary resemblance in habitat which existed betwecn another Nemertean (whose anterior extremity exactly answered to that of a Lineüs or Cerebratulus, and carried two well-pronounced fissures), and this single specimen of Lobilabrum. Once the doubt was raised, Dr, Hubrecht pursued the investigation by purposely cutting off the tip of the snout in one of the last-mentioned species, in a direction vertical to the body axis. Immediately the curious arrangement of the lobed and tentaculated lips which had hitherto been limited to the genus Lobilabrum appeared, the animal operated on lived for several weeks, and afterwards longitudinal sections showed that an epidcrmal covering had made its appearance identical with what had been found in the Lobilabrum specimen. Considering these results with the fact of the habitat amongst bivalve shells, Dr. Hubrecht concluded that the genus of De Blainville had becn founded on a specimen the tip of whose snout had been severed by an oyster into whose open shell it was stealthily trying to penetrate.

Amidst the many contributions to vol. ii. of especial importance is a memoir by G. C. J. Vosmaër, on the sponges belonging to the family of the Desmacidinæ; siliceous forms known by bow, anchor, and bihamate spicules with some criticisms on the works of Bowerbank and others. It is a well-known fact that the late Mr. Bowerbank did "not sufficiently understand the German language," and his remarks on Oscar Schmidt's important works in the preface in vol. iii. of the "Monograph of the British Spongidx" were rendered still more negligent by the many typographical errors. Surely Vosmaër is wrong in the assertion that "only one man in England, Sir Wyville Thomson, has declared himself in favour of Schmidt's views" on classification, and we would venture to assert that of the classifications of the siliceous sponges invented by Bowerbank, Gray, or Carter, none have replaced that of Oscar Schmidt as recently modified. While promising to publish a more extensive memoir on the Desmacidinæ, with the indispensable illustrations of the new species, Vosmaër's prisent enumeration of the species is of very great value. As most of Bowerbank's type species are in existencc, we trust that Vosmaër may consult the e ere publishing his final memoir, as while we acknowledge as a fact that Dr. Bowerbank was a most accurate and painstaking observer, and a fairly good recorder of what he saw, experience has proved that he often, from one cause or another, overlooked even quite easily recognised characters. Vosmaër accepts 16 genera and enumerates $\mathrm{I} 62$ species. Of these he naively remarks :- "As the result of my study of them, plenty of synonyms have been described, but I have never felt the necessity of making two species from one!" F. E. Schulze has given many examples in his splendid studies on the Ceraospongiæ, especially in his "Die Familie der Spongidx." Both Schmidt and Schulze have demonstrated that the word "species is to be used in a very wide sense" as regards the sponges. The scientific zoologist will hardly mind how wide, provided the definition thereof is such that, while it embraces all the forms it excludes none ; and, despite their heteromorphism - their plasticness, so to say - the sponges are, as a result of good honest work, getting arranged into species and genera that may satisfy the most fasticlious critic.

In the same volume of these "Notes" we find a paper by Prof. K. Martin, on a revision of the fossil Echini from the Tertiary strata of Java, which, working anew over the species described some thirty years ago by J. A. Herklots, quite reverses the conclusions of that author; and, instead of all or almost all of the species being different from existing forms, as insisted on by Herklots, Martin has succeeded in "demonstrating that by far the majority of all the well-preserved individuals could be identified with species still living in the Indian Ocean;" and he further mentions, citing the species found, and in addition the Mollusca, Crustacea, and Corals, that these Tertiary strata of Java contain no fossils which have also been found in extra-tropical Tertiary deposits, so that cven in the Tertiary period the separation of the fauna of the tropical oceans appears to have been quite as distinct as we find it in the present day.

Vol. iii. contains a very charming account of the habits of the harvest mouse (Mus minutus) and of its winter nest, by Prof. Schlegel. It is written-as indeed are very many of the contributions to these "Notes"--in English, but the language of this little history is worthy of the author's name. There are also by Prof. Schlegel some interesting notes on the zoological researches in West Africa, which wcre carried on under his directions; and an important contribution to our knowledge of the Comatulæ in a memoir on the species to be found in the Leyden Museum, by $P$. Herbert Carpenter. The collection at Leyden is one of considerable importance, owing to its containing a large proportion of the types of the species described by Johannes Müller in his classical memoir, "Ueber die Gattung Comatula, Lamk., und ihre Arten." It is noteworthy that the wholc of the Leyden collection of Comatulidæ were forwarded to Eton for study. For a possible trifling loss that a public museum may now and then sustain in a loan like this, there is sure to be an immense preponderance of gain.

A monograph of the African squirrels, with an enumeration of the specimens in the Leyden Museum by Dr. F. A. Jentink, commences vol. iv. While fairly and equitably reviewing the work on this group by Gray and Temminck he admits but two genera - Sciurus and Xerus, enumerating sixteen species of the former and three species of the latter genus. The synonymic lists appear to have been made out with the greatest care, of which care a very interesting example will be found in tracing the authority for the species Xerus capensis to Robert Kerr, who published his "Animal Kingdom, or Zoological System of the celebrated Sir Charles Linneus" in I792. Another contribution of Dr. Jentink which we find space to allude to is a revision of the Manidre in the Museum. Seven species are described in detail. Under Manis aurita, Hodg., we read that it is still questionable whether a Manis occurs in Japan. Temminck mentions that Von Siebold sent over to the Leyden Museum two pieces of the skin of a manis from Japan, but as these fragments are not now to be found in the collection, it is of course impossible to say to what species thev may have belonged. Mr. Serrurier, the director of the Ethnographical Museum at Leyden, informs Dr. Jentink that in the Japanese books at his disposal he finds nothing to justify the conclusion that the anteaters are inhabitants of Japan ; but it would appear that the Japanese do introduce them for medical purposes from China. The Japanese also relate that the anteaters catch ants in the following way:- The manis erects its scales and feigns to be dead; the ants creep in between the erected scales, after which the anteater 
again closes its scales and enters the water. He now again erects the scales, the ants are set floating, and are then swallowed by the anteater.

From a list of the Holothurians in the collection of the Leyden Museum, drawn up by Prof. Dr. Hubert Ludwig of Giessen, we find that the majority of the specimens in the Museum were incorrectly named, which is somewhat surprising; it seems also strange that of the species not so very long since described by Prof. Selenka the specimens are either sine patria or have the rather indefinite habitat of "Indian Ocean." The collection contains fiftytwo species, two being new ; most of them were obtained from the Oriental and Moluccan regions.

In vol. v. Dr. Jentink continues his very useful researches on the squirrels in the Museum. This time he treats of the American, European, and Asiatic squirrels; he acknowledges that the profound and extensive studies upon the American squirrels by Allen and Alston have made this group one of the best known among the Mammals; he enumerates ten species from America, forty from Europe and Asia. All the former are represented generally by numerous examples in the Museum, and of the latter only six species are among the desiderata.

The same volume contains "Notes of new species of the genus Megascolex, Templeton," by Dr. R. Horst. Very satisfactory evidence is given to show that Schmarda's genus Perichæta is but a synonym of Templeton's. Nine new species are described, chiefly from Sumatra, Java, and Japan; one, $M$. musicus, is described as living in the high mountain forests at Java, and is said to make a sharp interrupted noise during the night. The natives call it "tjatjing sondarie."

If in calling attention to these important contributions to our knowledge of the treasures of the Leyden Museum we have passed over the very numerous contributions to entomology, it is simply because our space forbids us referring to the immense number of new genera and species herein described; indeed these notes form a perfect magazine of entomology, and we feel sure are long ere this quite well known to all our entomological readers.

\section{PRZEVALSKY'S WILD HORSE}

Gr

REAT interest is attached to the question of the origin of our domestic animals, and especially to that of the horse-which is generally supposed not now to exist in an aboriginally wild state. Every fact bearing upon this subject is of importance, and the discovery by the great Russian traveller, Przevalsky, of a new wild horse, more nearly allied to the domestic horse than any previously known species, is certainly. well worthy of attention.

The horses, which constitute the genera Equus of Linnæus, and are the sole recent representatives of the family Equidce, fall naturally into two sub-genera, as was first shown by Gray in 1825 (Zool. Journ. i. p. 24I) Equus and Asinus.

The typical horses (Equus) are distinguishable from the asses (Asinus) by the presence of warts upon the hindlegs as well as upon the fore-legs, by their broad rounded hoofs, and by their tails beginning to throw off long hairs from the base, instead of having these hairs confined, as a sort of pencil, to the extremity of the tail. Up to a recent period all the wild species of Equus known to science were referable to the second of these sections, that is, to the sub-genus Asinus, known from Equus by the absence of warts or callosities on the hind-legs, by the contracted hoofs, and by the long hairs of the tail being restricted to the extremity of that organ. Of this group the best known species, commonly called wild asses and zebras, are (I) the wild ass of Upper Nubia (Equus taniopus), probably the origin of the domestic ass; (2) the wild ass of Persia and Kutch (E. onager); $(3)$ the hemippe or wild ass of the Syrian Desert (E. hemippus); (4) the kiang or wild ass of Tibet (E. hemionus); (5) the quagga (E. quagga) of South Africa; (6) the Burchell's zebra (E. burchelli) of Southern and Eastern Africa; ( 7$)$ the zebra (E. zebra) of Southern Africa. As already stated, these seven animals all possess the characters of the second sub-genus Asinus as above given, and no recent species of horse referable to the first sub-genus (Equus) was hitherto known to exist on the earth's surface, except the descendants of such as had been formerly in captivity.

Under the circumstances great interest was manifested when it was known that Przevalsky, on his return from his third great journey into Central Asia, had brought back with him to St. Petersburg an example of a new species of wild horse, which belonged, in some of its characters at least, to true Equus.

This new animal was described in $188 \mathrm{r}$ in a Russian journal by Mr. J. S. Poliatow, and dedicated to its discoverer as Equus przevalskii.

The recently issued German translation of Przevalsky's third journey ${ }^{1}$ enables us to give further particulars of this interesting discovery.

Przevalsky's wild horse has warts on its hind-legs as well as on its fore-legs, and has broad hoofs like the true horse. But the long hairs of the tail, instead of commencing at the base, do not begin until about half-way

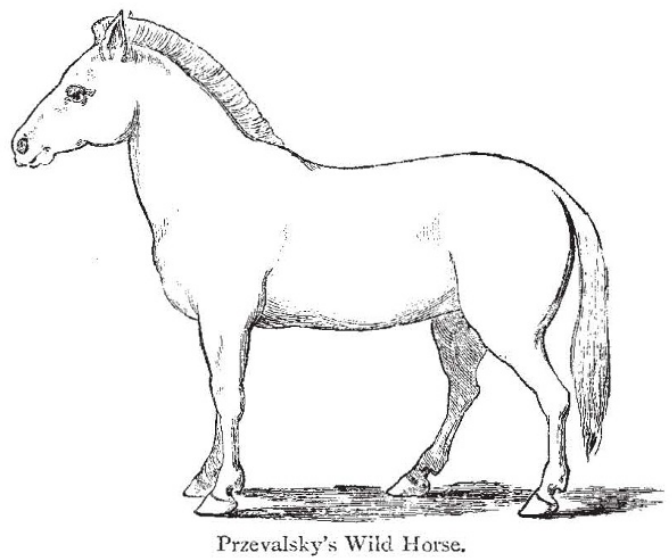

down the tail. In this respect Equus praevalskii is intermediate between the true horse and the asses. It also differs from typical Equus in having a short, erect mane, and in having no fore-lock, that is, no bunch of hairs in front of the mane falling down over the forehead. Nor has Przevalsky's horse any dorsal stripe, which, although by no means universal, is often found in the typical horses, and is almost always present in the asses. Its whole general colour is of a whitish gray, paler and whiter beneath, and reddish on the head. The legs are reddish to the knees, and thence blackish down to the hoofs. It is of small stature, but the legs are very thick and strong, and the head is large and heavy. The ears are smaller than those of the asses.

Przevalsky's wild horse inhabits the great Dsungarian Desert between the Altai and Tianschan Mountains, where it is called by the Tartars "Kertag," and by the Mongols "Statur." It is met with in troops of from five to fifteen individuals, led by an old stallion. Apparently the rest of these troops consist of mares, which all belong to the single stallion. They are lively animals, very shy, and with highly-developed organs of sight, hearing, and smelling.

They keep to the wildest parts of the desert, and are

I "Reisen in Tibet und am oberen Laut des Gelben Flusses in den Jahren Deutsche übertragen von Stein-Nordhcim. (Jena, 1884.) 